\title{
The Effects of Cash Flow Uncertainty and Working Capital on Non-Cash Flow Shock Returns
}

\author{
Shokrolah Khajavi ${ }^{1} \&$ Samaneh Ghoohestani ${ }^{1}$ \\ ${ }^{1}$ Department of Accounting, University of Shiraz, Shiraz, Iran \\ Correspondence: Shokrolah Khajavi, Associate Professor, Department of Accounting, University of Shiraz, \\ Shiraz, Iran. E-mail: shkhajavi@gmail.com
}

Received: January 25, 2015

Accepted: February 27, 2015

Online Published: March 25, 2015

doi:10.5539/ibr.v8n4p139

URL: http://dx.doi.org/10.5539/ibr.v8n4p139

\begin{abstract}
According to the findings of Elton et al. (1999) study, the stock return consists of several components which among them is the cash flow shock return. This means that in prior research, stock return variable were investigated regardless of cash flow shocks. This study investigated the influence of cash flow uncertainty and working capital on non-cash flow shock returns. In this regard, data were gathered from a sample of companies listed on Tehran Stock Exchange from 2004 to 2013. The research hypotheses were examined by multiple regressions. The research results showed that there is a significant relationship between working capital and non-cash flow shock returns. In addition, there is no significant relationship between cash flow uncertainty and non-cash flow shock returns.
\end{abstract}

Keywords: non-cash flow shock returns, cash flow uncertainty and working capital

\section{Introduction}

To calculate the cost of equity, conventional asset pricing tests apply average realized stock returns. However, measuring the cost of equity by realized return contains some errors due to information shocks (Elton, 1999). Realized returns include three components: the expected return, the return related to cash flow news, and the return related to discount rate news (Campbell, 1991). Among these constituents, only the expected return represents the firm's cost of equity.

Conventional asset pricing tests that use average realized stock returns as a criterion of expected returns implicitly assume that both realized stock returns on average and expected returns are equal. For extended periods of time, historical realized returns not equal to expected returns (Campbell, 1991; Elton, 1999; Ogneva, 2012). Therefore, these tests that apply average realized returns as a measure for expected returns are biased and the extent of the bias is related to the correlation between future cash flow shocks and the variable.

Ogneva (2012) divided the total realized return on stock $i$ into two components: cash flow shock returns and non-cash flow shock returns. Over the life of the firm the sum of cash flows should be equal to the sum of earnings, then a surprising earning can lead to a cash flow shock. The stock price reaction due to a revision in the prospection of the future cash flows can measure a cash flow shock (returns related to surprising earnings can be used to measuring cash flow shocks).

Lambert et al. $(2007,2009)$ state that reliable information about future cash flows lead to lower conditional covariances with the market, and as a result, lower conditional betas and lower expected returns.

External financing is more difficult for firms with uncertain cash flow and as a consequence, these firms have higher cost of capital; because such uncertainty leads to higher risk for capital providers. Then, firms with high degree of cash flow uncertainty have higher expected returns and then, higher non-cash flow shock returns.

Returns proportional with risk is one of the basic principles of financial theory. Each element of working capital equation can be considered as a certain element of risk-Returns spectrum. Difference firms with vary strategy classify these elements differently. In the value-adding Paradigm, when shareholder's return is greater than cost of capital (expected return), firm can create value for its shareholders. Then, increasing in the risk of working capital constitutes increase in firm's risk and shareholder's expected return. In this case, firm must provide higher return than expected return to create value. 
The reminder of the paper is organized as follows. Section II reviews the related literature, presents the paper's hypotheses. The sample selection procedures and the methodology are described in section III. Section IV presents the empirical analyses and results, Section V describes our conclusions.

\section{Literature Review and Hypotheses Development}

Following Fazzari, Hubbard, and Petersen (1988), a line of literature shows that firms use more of internal financing when they are faced with constrained external financing. With the increasing in cash flow uncertainty, the risk of external capital providers increases. Then, these firms have higher cost of capital that lead to more financially constrained to the extent that they must decrease investment due to limited capital (Minton \& Schrand, 1999).

Almeida and Campello (2010) argue that information asymmetries are important for constrained firms, but immaterial for unconstrained firms. The latter choose cash flow as their first option merely because of the existence of adjustment costs, particularly flotation costs (Strebulaev, 2007). So how should this circumstance change the conception of the preference hierarchy hypothesis? Almeida and Campello (2010) state, constrained firms are strongly dependent on internal cash flow and have insufficient cash flow for their investment. In other words, in these companies deciding about investment is depended on internally generated cash flows. In contrast, unconstrained firms don't have serious problem and are free to choose their investments as they do not face considerable adverse selection or agency problems. Hence, investment is exogenous for unconstrained firms and endogenous for constrained firms. As a result, constrained firms have to "absorb" cash flow shocks and then decide how much investment they can finance.

Easley and O'Hara (2004) study the effect of information asymmetry on the cost of equity. According to their study, the investors with weak information demand compensation for their informational disadvantage versus investors with more information. Hughes et al. (2007) show that after controlling for factor betas, there is no cross-sectional relation between expected returns and the level of information asymmetry, although information asymmetry exerts influence on factor premiums. Lambert et al. (2009) show that after controlling for the average precision of information, the degree of information asymmetry is not related to expected returns.

Ogneva (2012) stated that for stocks with poor (good) accrual quality, cash flow shocks are relatively lower (higher). The lower (higher) cash flow shocks is compensated with higher (lower) expected returns of poor (good) accrual quality firms. She argues that after removing cash flow shocks, there is a negative relation between future realized returns and accrual quality. When cash flow shocks are excluded by firm-specific return decomposition, the premiums relating to accrual quality are both statistically and economically significant in standard asset pricing tests.

Fakhari and Roohi (2013) found that surplus stock returns are positively associated with holding cash flow and working capital. In a similar vein, managing working capital is negatively related to cost of equity. Moradi and Najjar (2013) showed that there is a negative relationship between net working capital and surplus stock return.

Charles (2008) argued that working capital policy is related to decisions about current assets and current liabilities (issues such as their constitutive, their using and their mixture affect the risk versus return characteristics of company). Working capital policies can impact on shareholder wealth through affecting on firm's expected returns and the risk relating to these returns.

To summarize, while analytical models represent a negative relation between cash flow uncertainty, working capital and cost of equity, the findings from empirical research about cost of equity (expected returns) provides mixed evidence.

Rappaport state that one of the factors that create value for shareholders, is working capital. Decline in surplus investment in working capital increase the worth of shareholders (Fakhari \& Roohi, 2013). On the other hand, Deloof (2003) argued that greater investment in working capital lead to greater investment opportunity and lower cost of equity.

These arguments lead us to the following hypotheses:

H1: The non-cash flow shock returns are not affected by the cash flow uncertainty.

$H 2$. The non-cash flow shock returns are not affected by the working capital.

\section{Method}

Our sample is composed of Iranian firms listed from 2004 to 2013. We exclude financial firms. We also require all firms to have complete financial data throughout the sample period. Our final sample includes 1070 firm-year observations. 
To investigate the effects of cash flow uncertainty and working capital on non-cash flow shock returns, we use the method that Ogneva (2012) create. In this regard, the following regression is estimated using individual stock returns (the $i$ subscript refers to individual stocks):

$$
r_{i, t+1}^{N C F}=b_{0}+b_{1} \text { Dum }_{1}+b_{2} \text { Dum }_{2}+b_{3} B_{E T A_{i t}}+b_{4} M K T V_{i t}+b_{5} \text { BMRATIO }_{i t}+\varepsilon_{i t},
$$

Where,

$r_{i, t+1}^{N C F}$ : Non-cash flow shock returns

Dum $_{1}$ : We distribute all observations, according to cash flow uncertainty, into two groups. Dummy (Dum $_{1}$ ) equals 1 if the cash flow uncertainty above the median and 0 otherwise.

Dum $_{2}$ : For the working capital, we do the same of cash flow uncertainty. After distribute all observations, according to working capital, into two groups, $\operatorname{Dummy}_{2}\left(\operatorname{Dum}_{2}\right)$ equals 1 if the working capital above the median and 0 otherwise.

$B E T A_{i t}=$ Firm's beta

$M K T V_{i t}=$ natural logarithm of market value of equity.

$B M R A T I O_{i t}=$ natural logarithm of the book-to-market ratio.

\subsection{Non-Cash Flow Shock Returns}

Ogneva (2012) express the total realized return on stock i as the sum of two components: the cash flow shock return and non-cash flow shock return:

$$
r_{i, t+1}=E\left(r_{i, t+1}\right)+r_{i, t+1}^{C F}+\varepsilon
$$

Where $r_{i, t+1}$ is realized return for period $t+1, \mathrm{E}(r i t+1)$ is the expected return for $t+1$.

The fitted values from these regressions represent cash flow shock returns $\left(r_{i, t+1}^{C F}\right)$, while the residuals plus the intercept constitute returns without cash flow shocks, which Ogneva (2012) call non-cash flow shock returns $\left(\mathrm{r}_{\mathrm{i}, \mathrm{N}+1}^{\mathrm{NCF}}\right)$.

Using the framework from accounting literature on earnings response coefficients (ERCs), we exclude cash flow shocks from realized stock returns. A revision in the expectation of the sum of future cash flows result in a stock price reaction. This stock price reaction can be used as a proxy of cash flow shock. On the other hand, future earnings can be applied as a measure of future cash flow and over the life of the firm the sum of both should be equal. Then, an earnings surprise leads to a cash flow.

Collins and Kothari (1989) state that given the different assumptions related to the time series process of earnings, only the current period earnings surprise can measure the cash flow shock:

$$
r_{i, t+1}^{C F}=\theta \times\left(U X_{t+1} / P_{t}\right)
$$

Where $r_{i, t+1}^{C F}$ is the cash flow shock part of the return for period $t+1 ; \theta$ is an ERC that is positively related to earnings surprise persistence and negatively related to the discount rate; $U X_{t+1}$ is the earnings surprise. Earnings surprise is calculated as follows:

$$
U X_{t+1}=E A R N_{i, t+1}-E_{t}\left(E A R N_{i, t+1}\right)
$$

One of the most important variables in our research is cash flow uncertainty. The used measure for uncertainty is cash flow shortfall (Cash Short) from Daniel et al. (2008). Cash flow shortfall is calculated as follows:

$$
\text { Cash flow short fall }=\text { Expected investment }+ \text { Expected dividend-Available Cash Flow }
$$

For expected dividend, we use dividend paid in the previous year and follow the methodology in DeAngelo and DeAngelo (1990), DeAngelo, DeAngelo, and Skinner (1994) and Healy and Palepu (1990).

For expected investment, we follow Daniel et al. (2008) and Deng et al. (2012). We first calculate the median of industry investment, which then is divided by industry lagged assets. To get the firms' expected investment, we multiply industry values by firms' lagged assets. Available cash flow is represented by Operating net cash flow

\section{Results}

\subsection{Descriptive Statistics}

Descriptive statistics for the sample are presented in Table 1: 
Table 1. Descriptive statistics

\begin{tabular}{lcccccc}
\hline & $\mathrm{r}_{\mathrm{i}, \mathrm{t}+1}^{\mathrm{CF}}$ & DUM $_{1}$ & DUM $_{2}$ & BM & MK & B \\
\hline Mean & 0.163 & 0.46 & 0.511 & -0.287 & 11.49 & 0.18 \\
Median & 0.009 & 0 & 1 & -0.255 & 11.40 & 0.245 \\
Maximum & 10.77 & 1 & 1 & 0.665 & 13.47 & 12.85 \\
Minimum & -3.56 & 0 & 0 & -2.3 & 9.85 & -22.5 \\
Std. Dev. & 0.763 & 0.5 & 0.5 & 0.356 & 0.67 & 1.09 \\
\hline
\end{tabular}

\subsection{Univariate Analysis}

In Section II, we conjecture that stocks with higher cash flow uncertainty and lower working capital experienced more negative cash flow shocks in our sample period. To test this conjecture, because each firm in the sample has a single expected return estimate, traditional tests that rely on the assumption of zero time-series correlation in returns can no longer be used. Instead, we estimate paneled regressions of non-cash flow shock returns on factor loadings with time random effects.

Table 2 reports Chow and Hausman test in our sample. According to this table, we must use panel data regression with random effects.

Table 2. Chow and Hausman tests

\begin{tabular}{lccc}
\hline & Statistic & Chi-Sq. d.f. & Prob. \\
\hline Chow test & 2.05 & 118 & 0.00 \\
Hausman test & 5.61 & 6 & 0.467 \\
\hline
\end{tabular}

The regression results in Table 3, show that the coefficient of $\mathrm{DUM}_{1}$ is not significant. This means that the first hypothesis is not confirmed and cash flow uncertainty doesn't have any effect on non-cash flow shock returns.

Further, the results show that firms with higher working capital have higher on non-cash flow shock returns. Thus, the second hypothesis is confirmed; this means that, working capital can affect on non-cash flow shock returns.

Table 3. Paneled regression with random effects

\begin{tabular}{lcccc}
\hline Variable & Coefficient & Std. Error & t-Statistic & Prob. \\
\hline MK & 0.179 & 0.03 & 4.86 & 0.000 \\
OLEV & 0.006 & 0.00 & 2.03 & 0.042 \\
DUM $_{2}$ & 0.131 & 0.04 & 2.89 & 0.003 \\
DUM $_{1}$ & -0.045 & 0.04 & -0.98 & 0.326 \\
BM & -0.529 & 0.07 & -7.11 & 0.000 \\
B & -0.004 & 0.00 & -2.23 & 0.026 \\
C & -2.11 & 0.41 & -5.06 & 0.000 \\
\hline Adjusted R-squared & 0.125 & Durbin-Watson stat & 1.85 \\
F-statistic & 23.58 & Prob(F-statistic) & 0.00 \\
\hline
\end{tabular}

\section{Conclusions}

Using a simple methodology that follows from the earnings response coefficient framework, we examine the effects of cash flows uncertainty and working capital on expected return (non-cash flow shock return). The statistical results show that there is no significant relationship between cash flow uncertainty and non-cash flow shock return. This meanings that, more elements other than cash flow uncertainty can affect on non-cash flow 
shock return and expected return. This result explained by capital structure in Iran that is bank based. Indeed whenever that companies stick in financial troubles can borrow from banks easily. Then, companies can resolve cash flow uncertainty whit financing activities, especially bank borrowing.

Moreover, according to statistical results, we document that there are positively significant relationship between working capital and non-cash flow shock return. Therefore, by increasing working capital, firm's cost of capital increases. Indeed increase in working capital arise form keeping excessive capital and indicate firms disability on effective use of financial resource.

\section{References}

Altman, E. (1968). Financial ratios, discriminant analysis, and the prediction of corporate bankruptcy. Journal of Finance, 23, 589-609. http://dx.doi.org/10.1111/j.1540-6261.1968.tb00843.x

Campbell, J. Y. (1991). A variance decomposition for stock returns. Economic Journal, 101(405), 157-79. http://dx.doi.org/10.2307/2233809

Chaya, J. B., \& Suh, J. (2009). Payout policy and cash-flow uncertainty. Journal of Financial Economics, 93, 88-107. http://dx.doi.org/10.1016/j.jfineco.2008.12.001

Collins, D. W., \& Kothari, S. P. (1989). An analysis of intertemporal and crosssectional determinants of earnings response coefficients. Journal of Accounting and Economics, 11(2-3), 143-181. http://dx.doi.org/10.1016/0165-4101(89)90004-9

Daniel, N. D., Denis, D. J., \& Naveen, L. (2008). Dividends, investment, and financial flexibility. Working paper.

DeAngelo, H., \& DeAngelo, L. (1990). Dividend policy and financial distress: An empirical investigation of troubled NYSE firms. Journal of Finance, 45, 1415-1431. http://dx.doi.org/10.1111/j.1540-6261.1990.tb03721.x

Deloof, M. (2003). Does working capital management affect profitability of Belgian firms? Journal of Business Finance \& Accounting, 30(3)\&(4), 585. Blackwell Publishing. http://dx.doi.org/10.1111/1468-5957.00008

Deng, S., \& Mingqing, W. (2013). Dividends, investment and cash flow uncertainty: Evidence from China. International Review of Economics and Finance, 27, 112-124. http://dx. doi.org/10.1016/j.iref.2012.09.005

Easley, D., \& O'Hara, M. (2004). Information and the cost of capital. Journal of Finance, 59(4), 1553-83. http://dx.doi.org/10.1111/j.1540-6261.2004.00672.x

Elton, J. (1999). Expected return, realized return, and asset pricing tests. Journal of Finance, 54, 1199-1220. http://dx.doi.org/10.1111/0022-1082.00144

Fakhari, H., \& Roohi, G. (2013). Investigate the effects of holding cash flow and working capital management on firm's surplus return. Journal of Accounting Knowledge, 14, 27-49.

Foruoghi, D., Amiri, H., \& Mohammadian, M. (2014). Analyzing the effects of accrual quality on non-cash flow shock return. Journal of Accounting and Auditing Review, 21, 173-188.

Hughes, J., \& Liu, J. (2007). Information asymmetry, diversification, and cost of capital. The Accounting Review, 82(3), 705-729. http://dx.doi.org/10.2308/accr.2007.82.3.705

Kormendi, R., \& Lipe, R. (1987). Earnings innovations, earnings persistence, and stock returns. Journal of Business, 60, 323-346. http://dx.doi.org/10.1086/296400

Lambert, R., Leuz, C., \& Verrecchia, R. (2007). Accounting information, disclosure, and the cost of capital. Journal of Accounting Research, 45, 385-420. http://dx.doi.org/10.1111/j.1475-679X.2007.00238.x

Lazaridis, I., \& Tryfonidis, D. (2005). The relationship between working capital management and profitability of listed companies in the Athens stock exchange. Journal of Financial Management and Analysis, 19(1).

Minton, B., \& Schrand, C. (1999). The impact of cash flow volatility on discretionary investment and the costs of debt and equity financing. Journal of Financial Economics, 54, 423-460. http://.dx.doi.org/10.1016/S0304-405X(99)00042-2

Moradi, M., \& Najjar, M. (2013). The relationship between surplus working capital and surplus stock return in the Tehran Stock Exchange. Journal of Accounting and Auditing Review, 20, 109-132.

O'Hara, M. (2003). Presidential address: Liquidity and price discovery. Journal of Finance, 58(4), 1335-1354. http://dx.doi.org/10.1111/1540-6261.00569

Ogneva, M. (2012). Accrual quality, realized returns, and expected returns: The importance of controlling for 
cash flow shocks. The Accounting Review, 87(4), 1415-1444. http://dx.doi.org/10.2308/accr-10276

Vuolteenaho, T. (2002). What drives firm-level stock returns? The Journal of Finance, 57, $233-264$. http://dx.doi.org/10.3386/w8240

\section{Copyrights}

Copyright for this article is retained by the author(s), with first publication rights granted to the journal.

This is an open-access article distributed under the terms and conditions of the Creative Commons Attribution license (http://creativecommons.org/licenses/by/3.0/). 